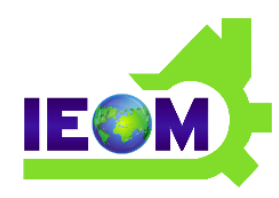

IEOM Society International

\section{International Journal of Industrial Engineering and Operations Management (IJIEOM) \\ Volume 2, No. 1, October 2020 \\ pp. $24-41$}

\title{
Optimization on the Shop Floor - A Business Simulation Approach
}

\author{
Patrick Pötters \\ Laboratory for Machine Tools and Production Engineering (WZL), Department of Metrology and \\ Quality Management at RWTH Aachen, Steinbachstraße 19, 52074 Aachen, Germany \\ $\&$ \\ University of Applied Sciences Koblenz, Faculty of Operations Management, \\ Konrad-Zuse-Str. 1, 56075 Koblenz, Germany \\ poetters@hs-koblenz.de \\ Robert H. Schmitt \\ Laboratory for Machine Tools and Production Engineering (WZL), Department of Metrology and \\ Quality Management at RWTH Aachen, Steinbachstraße 19, 52074 Aachen, Germany \\ r.schmitt@wzl.rwth-aachen.de \\ Bert Leyendecker \\ University of Applied Sciences Koblenz, Faculty of Operations Management, \\ Konrad-Zuse-Str. 1, 56075 Koblenz, Germany \\ leyendecker@hs-koblenz.de \\ Jasmin Ohlig \\ University of Applied Sciences Koblenz, Faculty of Operations Management, \\ Konrad-Zuse-Str. 1, 56075 Koblenz, Germany \\ ohlig@hs-koblenz.de \\ https://doi.org/10.46254/j.ieom.20200103
}

\begin{abstract}
Assembly processes can be optimized with various methods. However, it is difficult to evaluate the effectiveness and interaction of these methods. To date, shop floor improvement methods in series production, such as the methods under investigation 5S, Poka Yoke, Kanban, and Standard Work Sheet, have not been scientifically analyzed using a business simulation. This study is aimed at closing this research gap by conducting a business simulation and analyzing the generated data using the design of experiments. This combination represents a new form of research. For the design of experiments, full factorial design with four factors was used. Lead time is selected as the KPI. By analyzing the lean methods that were investigated in this study, both main effects and interactions were found. Results show that it is useful to apply at least one optimization method, whereby Poka Yoke has the most significant impact on the lead time. Researchers in the field of optimization methods can base their investigations on this study.
\end{abstract}

\section{ARTICLE INFO}

Received August 15, 2019

Received in revised form April 30, 2020

Accepted

May 01, 2020

\section{KEYWORDS}

Assembly

Optimization; Lean

Methods; Business

Simulation; Design of

Experiments; Lean Six Sigma 


\section{Introduction and Motivation}

Globalization and technological innovation, just to name a few of current megatrends, lead nowadays to a high number of challenges for companies. To be successful, companies are forced to rise up to these challenges. The adaptation of business processes to meet the market requirements is a significant way to do so (Dombrowski/Crespo, 2008). Shop floor processes can be optimized by a lot of different tools and methods (Schmitt/Pfeiffer, 2015), including for example Poka Yoke, 5S, Lean Management, and Kanban. An efficient transfer of these methods into their manufacturing chain is a challenge for many companies. Not only the choice of the right method but also the effectiveness of the respective method is difficult to estimate (Dombrowski/Crespo, 2008). Companies are often not able to evaluate whether process efficiency and effectivity have been increased or not, after the implementation of these methods (Suzaki, 1993). Even experts in this field can only assess this based on their experience. Current research states, that a vast number of different methods for manufacturing optimization are available (Baumgaertner, 2006). To address this real-life problem, the impact of lean methods on the assembly of a series production is quantified through a business simulation at a model factory. A business simulation is a reproduction of reality as a dynamic model that is used to research and reproduce processes, for which an implementation in reality would be too expensive, time-consuming and fraught with risk (Hitzler et al., 2011). To date, lean methods in series production have not been scientifically analyzed using a business simulation. A business simulation presents an academically recognized method (Duke, 1996). Nonetheless, experiments like this have not been conducted yet. The following challenges are based on the choice of the right tools and methods and the right setup of the experiment, including the collection of data and the human factor. This study aims at closing the research gap by systematically analyzing series manufacturing. The following main hypothesis is given:

"The effectiveness of selected lean methods can be demonstrated via a developed model in form of a business simulation".

Out of this, further hypotheses for each lean method can be derived:

"The effectiveness of Poka Yoke can be demonstrated via a developed model in form of a business simulation".

"The effectiveness of $5 S$ can be demonstrated via a developed model in form of a business simulation".

"The effectiveness of Kanban can be demonstrated via a developed model in form of a business simulation".

"The effectiveness of Standard Work Sheet can be demonstrated via a developed model in form of a business simulation".

A model, consisting of a business simulation, which supports the assessment of the usage of lean methods in the assembly, was developed to test the hypotheses. Therefore, a systematic analysis of series assembly with a simulation and the hereby generated data using design of experiments (DoE) is conducted to close the research gap. Additionally, the deployment of lean tools in assembly is measured and evaluated. Consequently, enterprises can gather indications that have been empirically verified based on the impact of different methods. They can take these into account during the selection process for the right optimization method within their own company.

\section{Literature Review}

Based on detailed literature research, the field of process optimization methods is extensive. Lean Management, Process Management, Six Sigma, and Total Quality Management can all be identified as popular approaches regarding process optimization. Of these, Lean Management is one of the most popular approaches (Arnheiter/Maleyeff, 2005). Hence, the impact of selected lean methods will be tested as part of a business simulation and evaluated with the design of experiments. Therefore, Lean Management and selected lean methods, as well as business simulation and the design of experiments, will be considered after defining process optimization methods after demonstrating the need for process optimization.

\subsection{Need for Process Optimization}

Today's megatrends lead to various challenges for companies. To remain successful businesses are forced to cope. The adaptation of business processes to meet market requirements is a significant way to do so (Dombrowski/Crespo, 2008). As companies face an increasing environmental complexity (Nadarajah/Kadir, 2014), continuous process improvements are needed to survive in a dynamic competition (Gibbons/Burgess, 2010; Allweyer, 2005). Four megatrends reinforce the need for process optimization. They are characterized as follows:

1. Globalization of markets: Globalization represents the increasing fusion of economic areas, which leads to predatory competition (Arndt, 2015; Rothlauf, 2004). The creation of competitive cost structures through efficient process design is indispensable (Allweyer, 2005).

2. Increasing customer requirements: In globalized markets, supply exceeds demand. This dominance of the buyer side shapes the concept of the buyer market (Rothlauf, 2004). Due to the dominance of demand, companies are 
obliged to respond to customer wishes and the demands for increasingly individualized products (Arndt, 2015; Kumar/Harms, 2004). A high degree of business process flexibility is required to meet fluctuating customer needs (Singh/Singh, 2012).

3. Technological progress: Technological progress provides companies with new opportunities for the rapid spread of information (Aparecida da Silva/Pelogia Martins Damian/Dallavalle de Pádua, 2012) and opens up new distribution channels (Allweyer, 2005). On the one hand, technological advances enable the cost-effective and efficient design of business processes, on the other hand, they require the integration of new technical features into products (Arndt, 2015).

4. Shortened product lifecycles: The product lifecycle (the period between the release of a product and its replacement by successor products) becomes increasingly shorter due to the first three megatrends mentioned before (Allweyer, 2005; Arndt, 2015). A company has a competitive advantage if it can bring new product innovations to the market faster than its competitors (Allweyer, 2005). To survive in times of increasingly shorter product life cycles, efficient design and speed-up of development processes and market launches are necessary (Allweyer, 2005).

Adapting to these changed conditions should not be a one-off task, but an ongoing process (Schmelzer/Sesselmann, 2008).

\subsection{Process Optimization Methods}

"Process optimization methods" refer to the improvement of existing business processes by applying certain methods to operate successfully in the market (Kruse, 2009). The fulfillment of crucial customer requirements, such as high product quality, can be promoted by identifying weaknesses in a process and improving them (Gericke/Bayer/Kühn/Rausch/Strobl, 2013). Process optimization methods are used for this purpose. They provide systematic approaches for the design of efficient processes and thus for the improvement of products and services (Alby/Braun/Pfleger,

n.d.).

Karlstedt (2013) defines a process as a series of correlating activities that transform inputs into results (Karlstedt, 2013). In a business context, it is equated with the term "business process". A business process is related to a collection of activities that provide value for the customer (Hammer/Champy, 1994). "Optimization" means that the best possible solution for a given problem is sought (Stiller, n.d.). Finally, "method" stands for a clearly defined process to achieve defined goals. Methods are based on rules and instructions (Alby/Braun/Pfleger, n.d.). Process optimization distinguishes between evolutionary and revolutionary optimization. Evolutionary process optimization deals with step-by-step improvements in day-to-day operations. There are no effects on existing processes (Pohanka, 2010). To improve motivation, evolutionary process optimization involves the employees in the change process (Thaler, 1999). Thus, it represents a hybrid approach (Pohanka, 2010). The revolutionary process optimization deals with the redesign of business processes within the framework of business process engineering (Pohanka, 2010). It is organized in project form and follows the top-down approach. Revolutionary process optimization has an impact on other processes and often implies staff resistance (Pohanka, 2010; Arndt, 2015).

\subsection{Lean Management}

Lean Management is a process optimization method that has its origins in Japan and the Toyota Production System (Ohno, 2013). Thus, it has its roots in the automotive industry. However, it is not only applied in this sector but in many other industries, too (Dickmann, 2015). Regardless of the sector where it is applied, the aim of Lean Management is to identify and eliminate waste in production processes to provide good quality in a short delivery time at the least possible costs (Bertagnolli, 2018). The process is focused on the customer and their satisfaction, so dynamic customer requirements should be fulfilled (Pfeiffer/Weiß, 1992). Because Lean Management is considered a philosophy, every single person within the company must live this philosophy (Asbach/Kamp, 2014).

Lean Management consists of different lean principles. Various authors have created different principles, but one of the most popular principles is the five principles of lean thinking by Womack and Jones (Womack/Jones, 2013). The five principles are called value, value stream, flow, pull and perfection (Campos, 2013). The value of a product or service is defined by the customer and generated by the organization. The requirement for implementing this principle is to know the customer's needs (Womack/Jones, 2013). The second principle is the identification of the value stream, which means that the entire supply chain has to be analyzed (Womack/Jones, 2013). Activities have to be differentiated between valuable, non-valuable and non-valuable but needed activities (Dall'Agnol et al., 2003). Customers are not willing to pay for non-valuable activities. For this reason, these activities are waste and have to be eliminated as fast as possible (Gorecki/Pautsch, 2013). The third principle "flow" means to ensure a production process without any interruptions (Dall'Agnol et al., 2003). A continuous flow is achieved, when the products flow continuously in a steady stream through 
the production. This leads to a reduction of lead time and waste (Liker/Meier, 2013). This principle is followed by the pull principle, which stands for a production that is initiated by the customer to ensure a demand-oriented production (Asbach/Kamp, 2014). In this way, overproduction and high inventory can be avoided (Womack/Jones, 2013). Tools that can be used to adhere to the pull principle are e.g. Kanban or Just in Time (Bertagnolli, 2018). Lastly, the principle perfection or a rather continuous improvement means an endless aspiration to perfection (Asbach/Kamp, 2014). Constant improvement of processes allows an organization to make products in shorter lead times and at lower costs (Campos, 2013). Methods, which can help implement this principle are for example Kaizen or the PDCA cycle (Bertagnolli, 2018). To adhere to these principles and to establish a lean production without waste, a large number of different lean methods and tools exists.

\subsection{Selection and Definitions of used Methods and KPI}

In the following, different lean methods are going to be selected, to identify their impact on the assembly of a series production. Therefore, a prevalence study (sample size of over 80 papers and books) was conducted. Moreover, a group discussion with seven experts in the field of assembly optimization was held and a quantitative survey in 2016 was conducted. These three pre-investigations serve as a basis for the selection of methods used in the business simulation. Altogether, over 70 lean methods were found. For the selection of the most popular lean methods, only those methods were considered, which had been included in all three pre-investigations. Taking these requirements into account, the methods 5S, Poka Yoke, Kanban, and Standard Work Sheet were selected as lean methods to be investigated in this study. As an example, Kanban is the top method regarding the prevalence study in literature with over 50 mentions in papers and books. Key Performance Indicators (KPIs) are suitable for verifying the effects of the used process optimization methods since their meaning allows a quantitative statement about the competitiveness and efficiency of the production system (Amann/Petzold, 2014; Sennheiser/Schnetzler, 2008). The KPI, which is measured in this study is the lead time. The lead time is defined as the period between the start (first process step) and the end (last process step) of an order (VDI 2870-1, 2012).

Subsequently, the four lean methods under investigation will be defined briefly.

The basic concept of the 5S method is the identification and elimination of major sources of waste, which leads to productivity in the business (Land et al., 2008). It concerns every workplace and is achieved through a clear standardization of each activity. The approach is comparatively cheap and improves profitability, efficiency, service, and safety at the workplace (Jaca et al., 2014). In addition, it can be applied in manufacturing as well as in administrative areas (Lunau et al., 2014). 5S stands for five Japanese terms:

1. Seiri (Sort: For an initial reorganization of the workplace all items that are not required for a certain activity or are available in duplicate are eliminated) (Becker, 2001)

2. Seiton (Set in order: For an efficient arrangement of relevant tools and materials every item has its place nearby in chronological order so that search times can be reduced) (Redmile, 2011)

3. Seiso (Shine: Required materials should be clean and an overview of the workspace should be given) (Morrisette, 2009)

4. Seiketsu (Standardize: Operating instructions and plans should be implemented and standardized for daily use at each workplace) (Dombrowski/Mielke, 2015)

5. Shitsuke (Sustain: The points 1 to 4 should be implemented sustainably and improved) (Ho, 1999)

5S is an easy-to-understand method, which requires a minimum implementation effort (Jaca et al., 2014). The removal of redundant tools and a sensible workspace layout result in the elimination of waste like search times and thus increases productivity (Neuhaus, 2016; Gorecki/Pautsch, 2018). It is important to involve the employees in the implementation of 5S. Visible success within a short period of time can lead to an increased work morale of the workforce and a greater willingness to be open for change (Bertagnolli, 2018). By creating and maintaining an organized, clean and highperformance work environment, the concept of $5 \mathrm{~S}$ forms the basis for further use of other process optimization methods and the ongoing implementation of Lean Production in business (Lunau et al., 2014; Bertagnolli, 2018).

Poka Yoke depicts a Japanese fault prevention method (Sondermann, 2013) using physical and technical provisions (Kamiske/Brauer, 2011). It is aimed at enabling zero-defect processes (Shingo, 1986) and the achievement of outstanding quality by not accepting mistakes and by taking measures to avoid them long term (Lunau et al., 2014). The focus lies on human labor-controlled processes since they are considered to be highly error-prone (Kamiske, 2015). The 
deployment of the Poka Yoke method can help identify and avoid these error sources in the production process (Theden/Colsman, 2013).

"Poka" is Japanese for an unfortunate mistake and "Yoke" means "to prevent" (Theden/Colsman, 2013). Altogether, "Poka Yoke" stands for the avoidance of unintentional mistakes (Kamiske/Brauer, 2011). The concept of Poka Yoke assumes, that people are not able to completely avoid unintentional errors, which can lead to defects in the manufactured products. For this reason, technical systems are used to prevent these unintentional errors occurring in the production process (Kamiske/Brauer, 2011). The basis for the implementation of Poka Yoke is the recognition of possible faults and the introduction of relevant measures. Firstly, any possible faults have to be identified. The faults and concerned processes must be analyzed to develop and select a solution to prevent any identified faults (Lunau et al., 2014; Lunau et al., 2013). The production process should be designed in a way, that errors cannot be made and therefore will be avoided (Fisher, 1999). Lastly, the developed solution is implemented and its effectiveness in preventing unintentional mistakes is checked (Lunau et al., 2014; Lunau et al., 2013).

An advantage of this method is that other process steps, such as quality control, are already carried out in the existing process steps and therefore no longer have to be conducted afterwards (Black, 2008). Moreover, it is applicable in a short period of time and without the need for high investments. The measures of Poka Yoke result in improved production processes and products and thus in a reduction of poor quality costs (Gorecki/Pautsch, 2018). Finally, the measures should be developed together with the employees on the shop floor (Sondermann, 2013), and this leads to greater acceptance by the employees (Gorecki/Pautsch, 2018).

Kanban, like Lean Management, also has its origins in Japan. It was developed by Taichi Ohno and implemented in the Toyota Production System (Dickmann, 2015). The word "Kanban" is Japanese and means "card". It represents a method for production process controlling to realize a just-in-time-system for inventory reduction $($ Ohno, 1988) and is a selfregulating system, which was designed to prevent waste through overproduction (Weber, 2009; Takeda, 2014). This means, that the required materials are provided at the right time at the right place in the right quantity (Zelewski et al., 2008). Therefore, it serves the concept of demand-oriented assembly (Womack/Jones, 1996), so assembly only starts on demand (Erlach, 2010). A Kanban system consists of a self-guiding control loop, which consistently initiates new demand. Different Kanban systems like Production Kanban or Transportation Kanban can be distinguished (Takeda, 2014).

The key element, when using Kanban, is the Kanban card. This card contains all important information for employees and management like quantity, material number, storage location and more (Weber, 2009). Manufacturing is triggered by these Kanban cards, which accompany the respective product until consumption (Schulte, 1991). Consequently, the pull-concept is implemented operatively by Kanban cards (Suri, 2010). There are several versions of Kanban existing, depending on the box itself and the number of boxes. Every box with material contains a Kanban card. If the material in the box is used up, the card must be pinned to the Kanban board, which triggers a new demand. Depending on the Kanban version, which is implemented, the new demand will be triggered, when either the first material is taken out of the box, when half of the material is used up or when the box is empty (Dickmann, 2015). Consequently, Kanban is structured like a cycle and is easy to implement, so that there are fewer disturbances (Dickmann, 2015). All in all, Kanban presents both, a simple and transparent control system and the possibility to minimize time-wasting (Sugimori, 1977).

The Standard Worksheet (SWS) is one of the main tools of standard work (Nicholas/Soni, 2005). It is an organizational resource, which can support the analysis, optimization, standardization, and documentation of work processes (Clement/Lacher, 2016). The SWS is a motion diagram, which shows the flow and layout of a process (Yagyu, 2009; Cudney et al., 2013). It has a clear starting and ending point and depicts the single steps, the employee has to do in their process (Nicholas/Soni, 2005). The worksheet contains a drawing of the workplace, the required auxiliary materials and both cycle time and frequency are indicated. Moreover, steps that need special quality checks or safety precautions are highlighted (Zidel, 2006). Each worker gets their standard worksheet, which is displayed in a prominent position in the workplace (Cudney et al., 2013).

The SWS method is used as a management tool by middle and lower management. It is applied to recognize and eliminate deviations from the standard because a process without waste is aspired. Therefore, the process has to be challenged for improvements continuously (Reitz, 2008). Because of the detailed description of the working steps, the SWS can also be used for the training of new workers (Yagyu, 2009). Altogether, the goal of the SWS method is to maintain a defined quality standard and to avoid errors due to a lack of knowledge of the work process (REFA, 2015).

\subsection{Business Simulation}


A Business Simulation is an instrument to reduce the complexity of real processes to transfer them into a situational model for reproducing economical relationships (Bloetz, 2015). In general, it is a scientifically accepted type of experiment (Bloetz, 2015). It can recreate situations that need a lot of planning. In doing so, a better comprehension and assessment can be achieved (Shah/Ward, 2003). The application of business games leads to an active integration of the participants and an interaction within the model (Ulrich, 2006). Moreover, it is advantageous to conduct the business games in neutral surroundings to unleash creativity and to eliminate organizational blindness (Künzel/Schrader, 2016). Participants experience an extract of a real process, in which determining factors can be varied arbitrarily to understand interdependencies (Stauberg et al., 2009).

Business simulations can be used for education, assistance and research purposes (Herz/Blaette, 2000); they are low cost and need little effort. It is a tool for companies to gain a competitive edge (Crookall, 2010). In the framework of this paper, a business game was developed to demonstrate the effectiveness of chosen lean methods.

\subsection{Design of Experiments}

The Design of Experiments (DoE) is used in the framework of planning and evaluating experimental series (Siebertz et al., 2010). The basis for the execution of the DoE is available data, which are gained through a series of experiments (Wieczorek, 2009). The runs are subject to the same frame conditions (Rath \& Strong Management Consultants, 2008). By means of the experiments, the DoE enables the generation of newly gained knowledge (Geiger/Kotte, 2008). The aim of the method is the analysis of cause-effect-relationships between process variables (X), which are called factors, and measurable output variables (Y) (Rath \& Strong Management Consultants, 2008). Hence, the change of output variables through the variety of factors can be statistically obtained. (Stagliano, 2004). Thereby, it can be determined, which factors have the strongest impact on the measured variable and which settings or combinations of factors lead to an improved and optimized process (Additive Soft- und Hardware für Technik und Wissenschaft GmbH, 2011). The identification of statistically significant effects occurs through the analysis of the p-value. This p-value is a defined level of significance, which is determined by the probability of error. This probability of error is to be as small as possible (Rath \& Strong Management Consultants, 2008).

To analyze the effectiveness of different optimization methods, the full-factorial design of the DoE is suitable, which considers all possible factor combinations (Rath \& Strong Management Consultants, 2008). In addition to the effects of the factors itself, the interdependency effects are taken into account. The effects of the sole factors are called main effects (Stagliano, 2004). They contain the difference of the mean values of a response variable through the variation of one factor (Additive Soft- und Hardware für Technik und Wissenschaft GmbH, 2011). In contrast, the interdependency effects take into account the variation through a combination of two or more input variables (Stagliano, 2004).

All in all, the DoE is a particularly economical and effective method to conduct experiments $(\mathrm{Kuehl}, 2009)$ and is widely spread, because of its standardized procedure and its high universality in engineering studies. For this paper, the software Minitab ${ }^{\circledR}$ was used to analyze the DoE.

\section{Business Simulation and Methodology}

In the following, the conception of the business simulation is explained. The production is grouped in two assembly areas, one final assembly, and a quality inspection. Fig. 1 shows the setup of the business simulation.

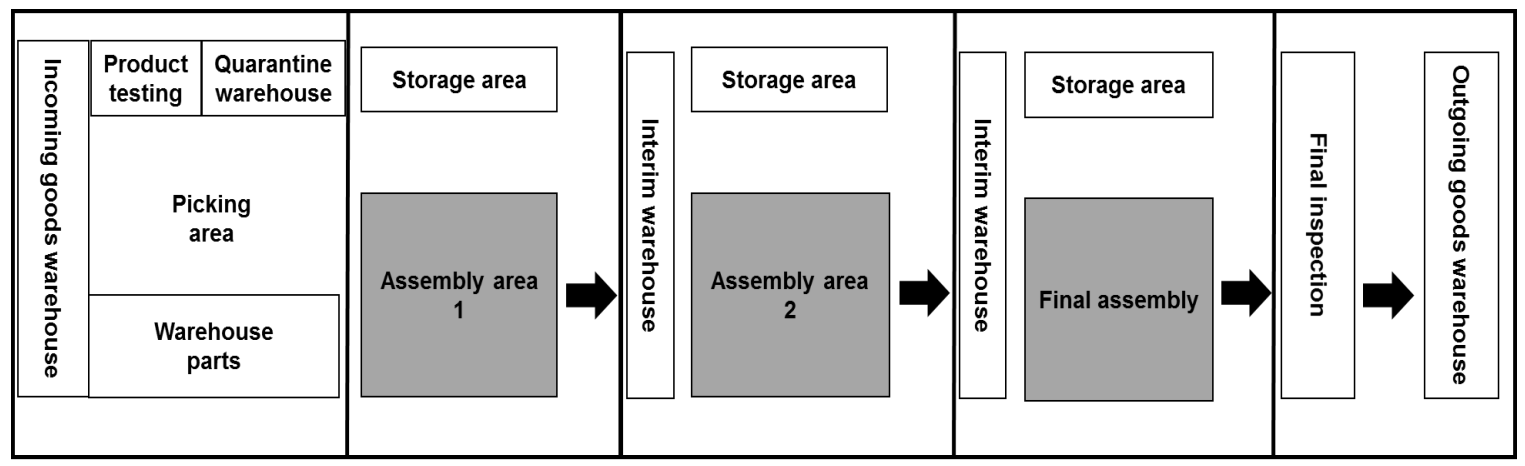

Figure 1: Setup of the business simulation

Six participants are needed to perform the business simulation, including one person per production stage, one at the final assembly as well as at the final inspection and two logisticians. In addition, five more participants of the research 
team are needed for time measurement. The product to be assembled consists of eight types of components and a total of 20 components, which are assembled by using push- and sliding connections. Fig. 2 shows a model truck and its components.

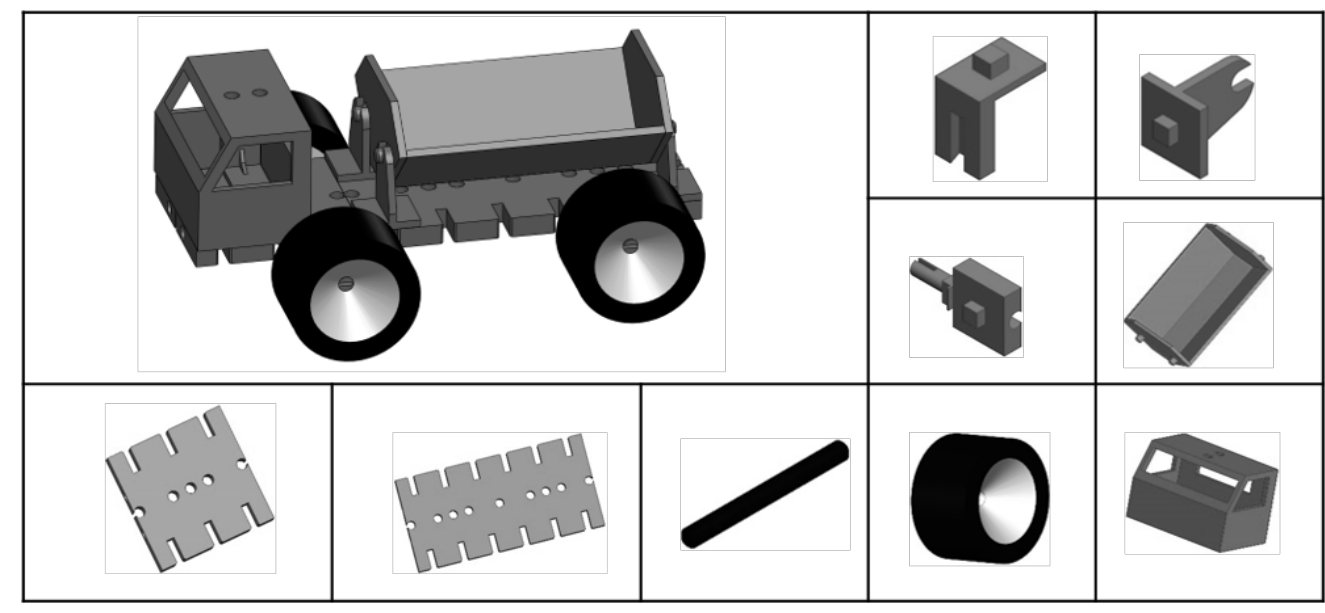

Figure 2: Model truck and components

The production process starts with incoming goods, which are first placed and checked in the storage area. If the materials are of high quality, they can be processed further. The assembly process begins at assembly area 1 . The employee removes the components for the first assembly step: $1 \mathrm{x}$ large plate, $1 \mathrm{x}$ small plate and $2 \mathrm{x}$ connecting rod from the specific storage area of the assembly station and joins them together as shown in Figure 3.

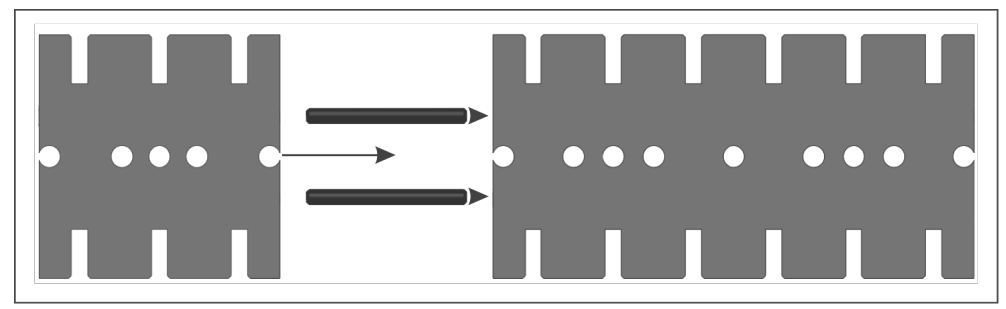

Figure 3: Assembly step 1

Between assembly area 1 and assembly area 2 and between assembly area 2 and the final assembly, small temporary storage areas are located. After completion of the first assembly step, the employee stores the semi-finished product in the temporary storage. The employee of assembly area 2 can remove the semi-finished product from the storage area and assemble further components. When collecting the semi-finished products from the small temporary storages the employees have to follow the "First-in-First-Out" principle. The employee of assembly area 2 needs $2 \mathrm{x}$ L-pieces, $4 \mathrm{x}$ axles, $4 \mathrm{x}$ tires, and $4 \mathrm{x}$ grippers. Two axles must be assembled on each side of the bottom of the plates, which act as a receptacle for the tires. The grippers are used to attach the truck bed in the following assembly step. For this reason, two grippers per side are attached to the large plate. The L-shapes are needed to stabilize the cab. Therefore, an L-shape is placed on each side of the small plate. This step is particularly challenging, because incorrect positioning of, for example, the grippers or the L-shapes, means that the following components cannot be assembled correctly. The components also have the property that two components per recess can be assembled. This means that a component can be assembled both on the top and at the same time on the bottom of the main component. Fig. 4 shows the exploded view of the semifinished product. It is stored between this assembly area and the final assembly. 


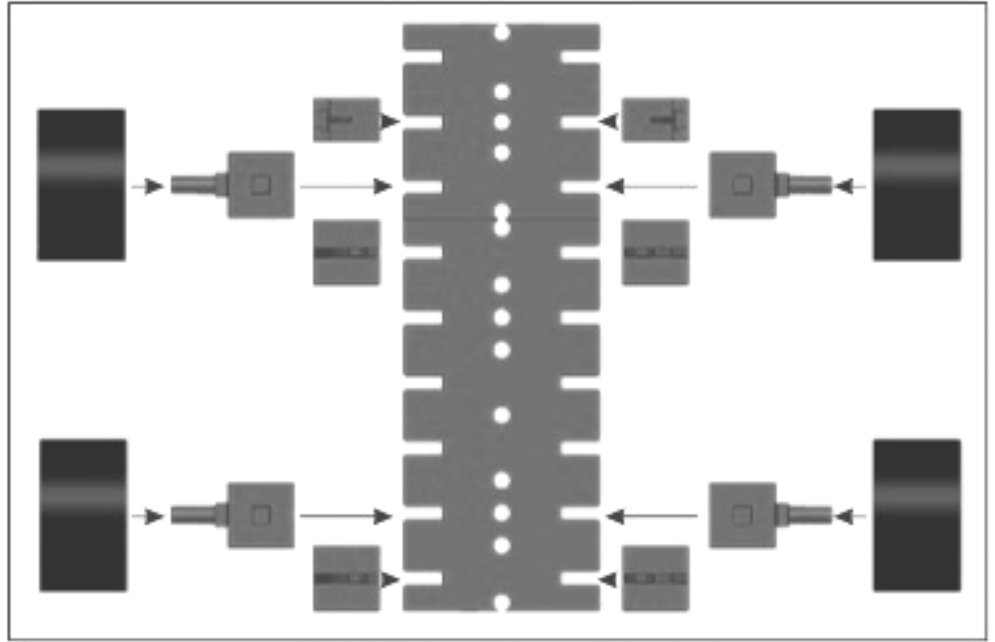

Figure 4: Assembly step 2

In the final assembly, the employee assembles the semi-finished product and completes the model truck. For this purpose, they assemble the driver's cab and the truck bed on the pre-assembled chassis of production area 2 (see fig. 5). After completion of the truck, the employee hands it over to final inspection. Finally, the quality employee checks if all components have been assembled correctly. If the truck is fault-free, it can be passed on to the outgoing goods warehouse. If there is a quality defect, the truck must be returned to assembly step 2 for rework.

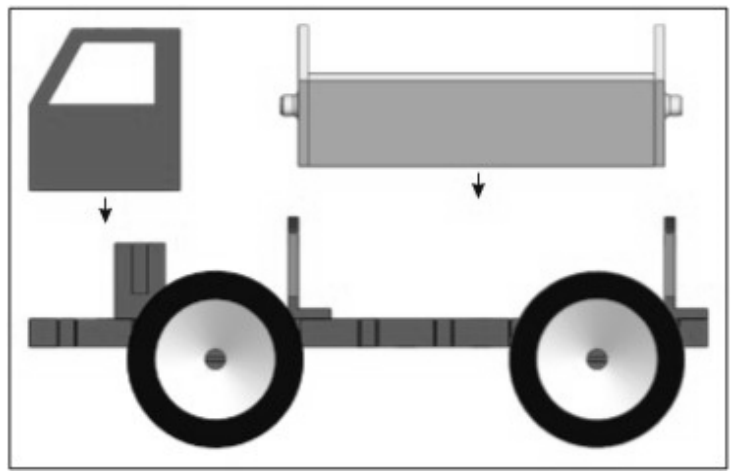

Figure 5: Assembly step 3

After a satisfying final inspection, the goods can be shipped to the customer. The outgoing goods warehouse is equivalent to the customer's incoming goods warehouse. Two logisticians manage the warehouse. Depending on the method used, the administration style varies, which will be explained later in this chapter. This business simulation takes 10 minutes. During this time the participants are requested to produce as many trucks as possible. To meet the delivery deadline given by the customer, the first truck has to be finished in two minutes. However, this time is only measured for the first truck.

In this simulation, the lead time starts with the removal of the first part at assembly area one and ends at the outgoing goods warehouse. The simulation is conducted in form of a game. A total of sixteen rounds are played, whereby the methods 5S, Poka Yoke, Kanban, and Standard Work Sheet are applied separately as well as in all possible combinations. Moreover, a "chaos" round is played, in which none of the methods are used. This approach enables benchmarking and leads to transparent findings. The "chaos" round had the following characteristics. Firstly, there was no standard of what the finished product should look like. An exemplary sequence for the different assembly stations was missing, too. Additionally, more material than required was provided, both in terms of type and quantity. The participants did not know the production steps and the material needed.

5S is only used in assembly areas one and two. This method is realized with printed pictures of the components used in the respective department and their optimal assembly sequence, as seen in fig. 6 . These printed pictures are called shadow boards. The shadow boards symbolize where the logisticians should place the materials. Hence, the components are in direct accessibility of the participants and search times can be reduced. There are no shadow boards in final assembly. 
In this area, an additional box is arranged, which contains the driver's cab and the trailer bed. According to the shadow boards, logisticians fill up materials as soon as one unit is taken from the marked area.

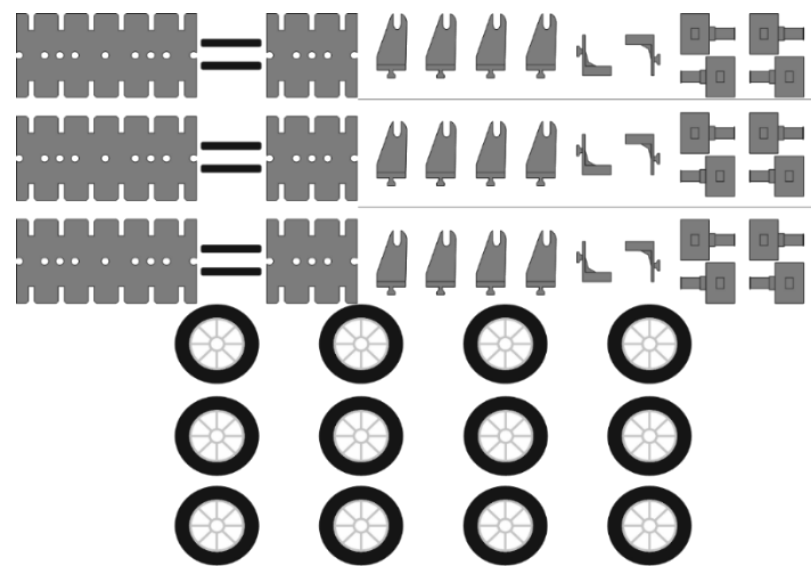

Figure 6: Shadow boards

Poka Yoke was applied by visualizing the connections in color. In detail, assembly points of the materials are marked by dots in the same color. Thus, the right connection of parts is ensured, and errors can be avoided. In the given business simulation, the Poka Yoke method focusses on assembly areas one and two. Rods, axes, tires, driver's cab, and the truck bed are excluded from markings. The marking of raw materials should be done before the experiment begins. It can also be recommended to mark the materials in the warehouse.

Kanban implies the reorder and supply of required materials via so-called Kanban cards. For this, each assembly step is equipped with two boxes. One of these is filled with the needed raw materials and the specified Kanban card. As soon as the participant removes the first material, they are requested to place the card in the second box. In this way, the Kanban card functions as a signal for the logisticians to refill raw materials at the specific assembly step. Furthermore, the Kanban card serves as an information medium, which contains information about the quantity of the required materials. Consequently, adequate supply should always be ensured. Kanban is applied at all three production stages.

When Standard Work Sheets are used, the process in every department is described and illustrated via pictures. This supports the employee in easily recreating the process steps displayed on the pictures.

Raw material prices at every station can be used as the calculation basis for the inventory costs at the end of each round.

\section{Results}

The business simulation was conducted with male and female students studying business administration as well as industrial engineering and management majoring in production management at the University of Applied Sciences Koblenz. They were neither familiar with the business simulation nor with the components that were used. To avoid a learning effect, each round was played with different students. Through a systematic analysis of a serial assembly, the deployment of lean tools on the assembly was measured and evaluated. Forty-eight rounds ( 3 replications with 16 rounds each) were played to achieve a full factorial DoE and to be able to analyze all factor combinations A significance level of $5 \%$ is selected. To evaluate the model quality, the R-squared value is calculated for the model lead time.

\subsection{Model "Lead Time"}

Currently, there is no recommendation as to which lean method can lead to lower lead time. As part of the experiment, the KPI lead time per truck was determined, from which an average value can be derived per run. A closer look will reveal where and with which methods the lowest lead time can be achieved. After a detailed statistical analysis, findings can be helpful for choosing the optimal lean method to reduce the lead time of a process. The bar chart in figure 7 shows the position of the reference line of the $5 \%$ significance level at 2.037 . 


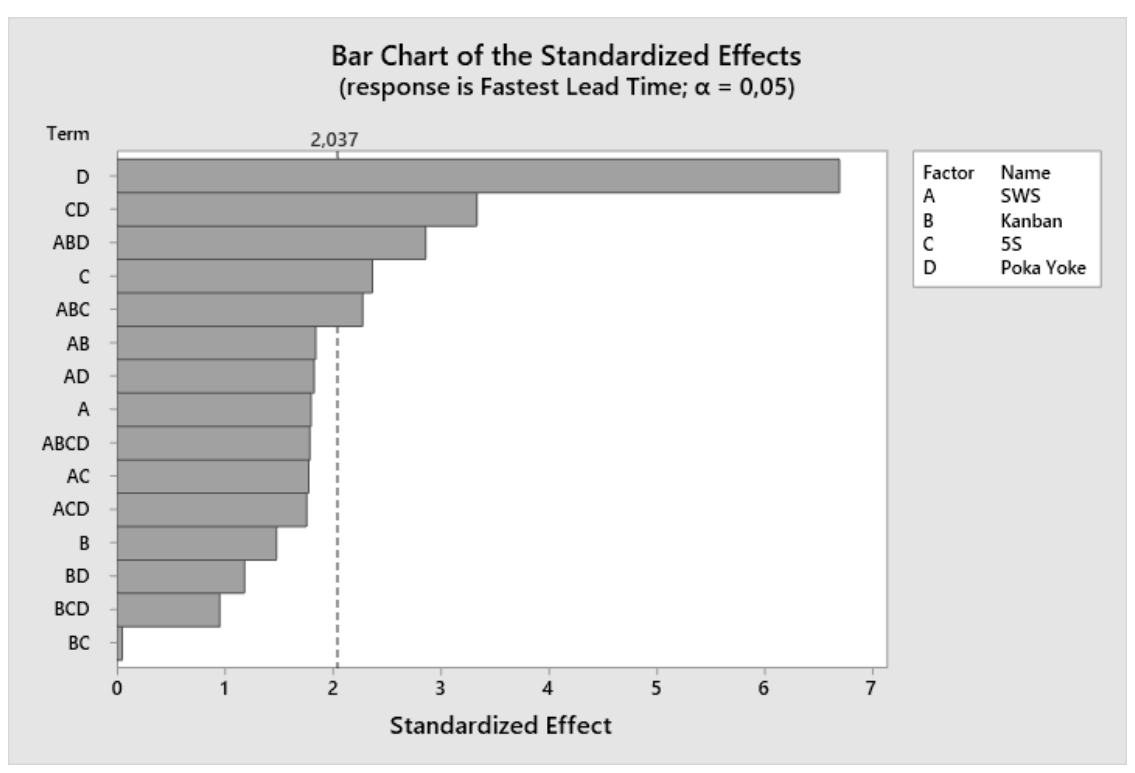

Figure 7: Bar Chart Model „Lead Time“

Altogether the bars of five model terms exceed the reference line and can, therefore, be considered statistically significant. The strongest impact on lead time can be observed when Poka Yoke is applied. Consequently, Poka Yoke leads to a significantly shorter lead time when compared to other lean methods. This impact is due to the production steps being considerably simplified for participants as they are based on color codes. Additional statistically significant effects can be observed for the interaction of 5S/Poka Yoke and SWS/Kanban/Poka Yoke. The reference line is also exceeded when $5 \mathrm{~S}$ is used exclusively or in combination SWS/Kanban/5S. Terms, whose bars don't exceed the reference line are not considered statistically significant. They have no impact on the lead time.

When summarizing the overview of the model, an $\mathrm{R}^{2}$ of $75.51 \%$ is identified, which means that the model accounts for $75.51 \%$ of the variation in data. However, the amended $\mathrm{R}^{2}$ is crucial for the model quality, which assumes a value of $64.02 \%$.

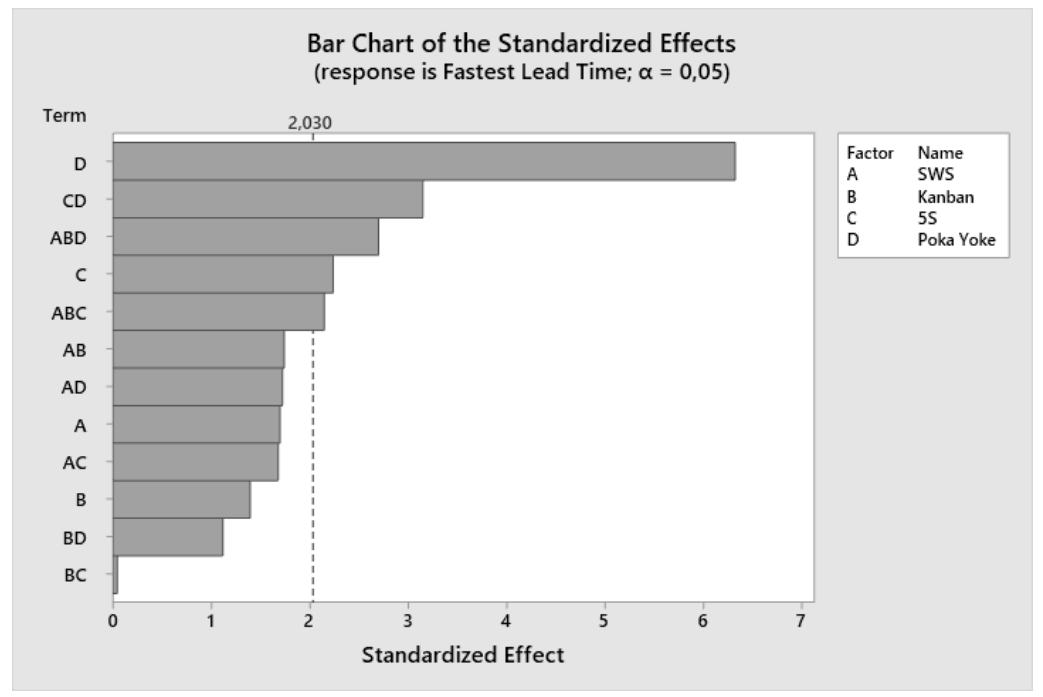

Figure 8: Bar Chart for factorial Adaptation Model „Lead Time“

\subsection{Factorial adaptation Model "Lead Time"}

The significant terms are to some extent two or three-factor interaction effects. Consequently, all individual factors contained in these terms will remain in the model. For example, the threeway interaction effect of SWS/Kanban/Poka Yoke was statistically significant in the initial analysis. To keep the hierarchy of the model, the terms SWS, Kanban, and 
Poka Yoke, as well as the integration of the specific two-factor-interactions, were not eliminated from the model despite being insignificant. In this way, the model adaptation requires the interaction of SWS/Kanban, SWS/Poka Yoke, and Kanban/Poka Yoke to be taken into account. A factorial adaptation exclusively eliminates the combination of $\mathrm{SWS} / \mathrm{Kanban} / 5 \mathrm{~S} /$ Poka Yoke, Kanban/5S/Poka Yoke, and Kanban/5S/Poka Yoke, as shown in Figure 8.

Once the non-significant terms have been eliminated, the reference line of the five-percent significance level shifts to 2.030. An average increase can be identified for the $p$-values following the model adaptation. Nevertheless, this will not lead to any new insights concerning statistical impacts on lead time. The strongest impact still results from applying the Poka Yoke method.

As a summary of the model, the R-squared is $70.01 \%$. The adjusted R-squared amounts to $59.73 \%$. A deterioration of $\mathrm{R}^{2}$, as well as the corrected $\mathrm{R}^{2}$, can be observed in the results of the adjusted model. Since the corrected $\mathrm{R}^{2}$ provides valuable insights into the model quality, a more accurate focus is essential. Therefore the corrected $\mathrm{R}^{2}$ considers the number of variables and reflects the explanatory power of one additional variable. This way the corrected coefficient of determination decreases by $4.29 \%$ following the factorial adaptation.

Main effect diagrams are used to show, which impact the factor levels "used" and "not used" have on lead time. For this purpose, the lean methods SWS, Kanban, 5S, and Poka Yoke are used for an individual view in figure 9.

Lead times are shown in days in the main effect diagram and interaction diagram. To achieve a better understanding, days are converted into minutes in the analysis.

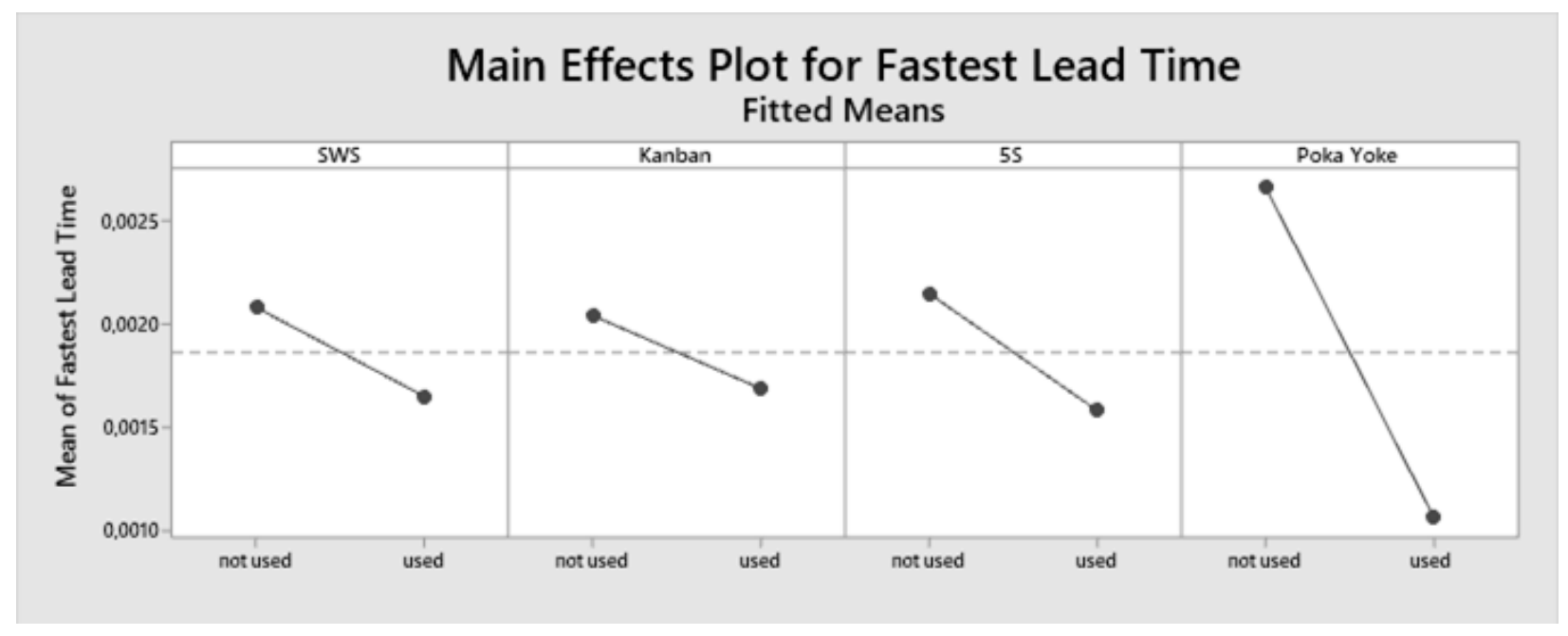

Figure 9: Main Effects Diagram Model „Lead Time"

Within the columns of individual factors, there is a differentiation between the specification "used" and "not used", which corresponds either to the application or abandonment of the respective method. The average lead time is at 2:40 minutes and is characterized by the horizontal dashed line. Considering the methods SWS and Kanban, it can be seen that the same effect occurs. Without the application of the respective method, the lead time is approximately 00:17 minutes higher than the mean. Nearly identical results are achieved when applying both methods in test runs. In both approach concepts, the lead time is reduced to 2:23 minutes. A closer look at 5S reveals that the lead time lies at 3:05 minutes without the application of $5 \mathrm{~S}$, which is above the mean value. By means of $5 \mathrm{~S}$, the lead time decreases to 2:16 minutes. Consequently, the effect shown here is considerably larger than the effects of SWS or Kanban. Poka Yoke has the most pronounced impact on the lead time, which is characterized by a steep incline of the straight line. When using this method, the lead time drops from 4:48 minutes to 1:32 minutes, which corresponds to a reduction of the lead time of 3:26 minutes between factor levels. When analyzing main effects, Poka Yoke is considered as the most effective lean approach under investigation to reduce the lead time.

It turns out, that the interaction of 5S and Poka Yoke is likewise significant. The interaction is shown in Figure 10. 


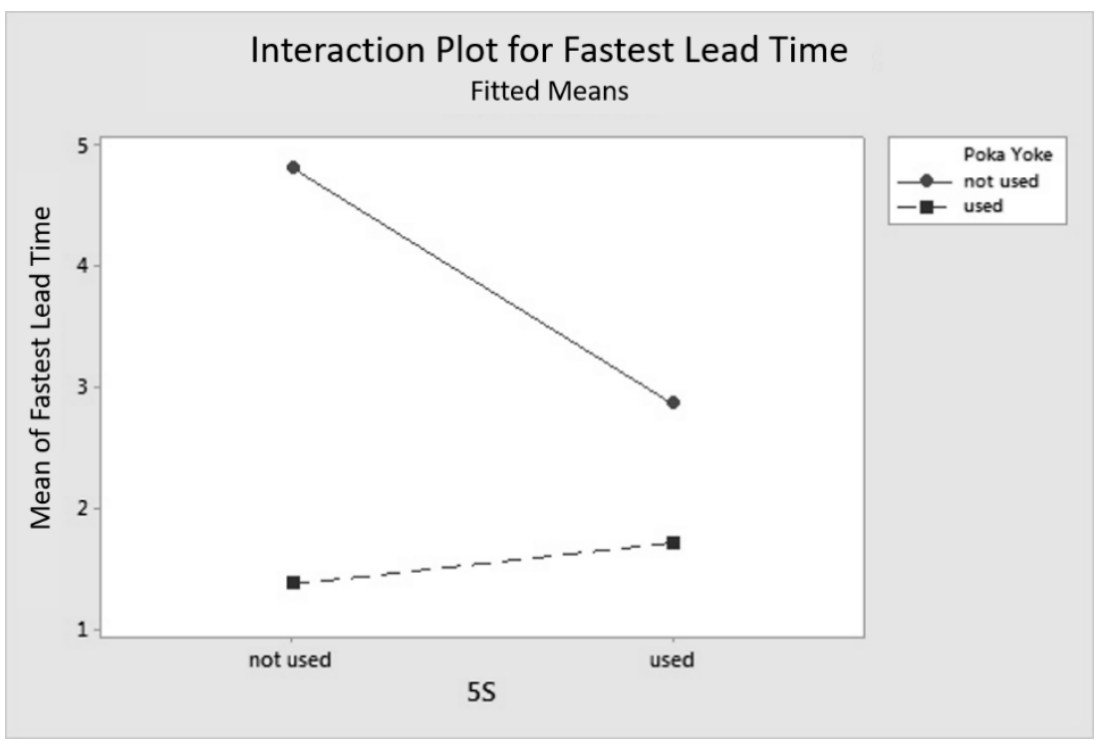

Figure 10: Interaction Diagram Model „Lead Time“

The 5S method is shown on the x-axis and divided into the characteristics "used" and "not used". The solid line indicates that Poka Yoke is not used, while the dashed line indicates that Poka Yoke is used. When neither of the lean methods is applied, an above-average lead time of 4:48 minutes becomes apparent in the test runs. The application of 5S solely entails a reduction of the response variable. The lead time is then at 2:51 minutes. This rapid drop is reflected in the steep incline of the straight line. The sole application of Poka Yoke leads to the lowest lead time of all possible factor combinations, which is 1:22 minutes. If both lean methods are used simultaneously, this will also affect lead time. In conclusion, the model adaptation shows that the application of Poka Yoke has the strongest impact on lead time. At least one lean method should be used. The combination of $5 \mathrm{~S} /$ Poka Yoke proves to be more effective than the sole application of $5 \mathrm{~S}$.

\subsection{Prognosis and target size optimization Model "Lead Time"}

After evaluating the data, a forecast was issued. The results show that the combination of $5 \mathrm{~S}$ and Poka Yoke can achieve an adjusted mean of approximately 0:52 minutes. The standard error of fitting (SE fit) is about 0:39 minutes. This is the estimated spread of the estimated mean. Within a confidence interval of $95 \%$, the values are approximately between 0:27 minutes and 2:11 minutes. In this prognosis model, too, the method Poka Yoke can be found in the top 3 results. The reference round leads to the worst result of the KPI lead time in the forecast. Using process optimization methods can therefore be considered effective.

Table 1: Extract of the forecast values

\begin{tabular}{|c|c|c|c|c|}
\hline Rank & Methods & Fit & $95 \%$-CI* & $95 \%$-PI*2 \\
\hline 1 & 5S, Poka Yoke & $00: 52$ & $-00: 27 ; 2: 11$ & $-02: 00 ; 03: 44$ \\
\hline 2 & Poka Yoke, SWS & $00: 52$ & $-00: 27 ; 2: 11$ & $-02: 00 ; 03: 44$ \\
\hline 3 & Kanban, Poka Yoke, SWS & $01: 13$ & $-00: 06 ; 2: 33$ & $-01: 39 ; 04: 06$ \\
\hline$\ldots$ & $\ldots$ & $\ldots$ & $\ldots$ & $\ldots$ \\
\hline 16 & Reference round & $07: 24$ & $06: 04 ; 8: 43$ & $04: 31 ; 10: 16$ \\
\hline
\end{tabular}

Legend:

${ }^{*} \mathrm{CI}=$ Confidence interval, $* 2=$ prediction interval

The target size optimization was used to find out which set of factors must be made to optimize the target variable. The combination of $5 \mathrm{~S}$ and Poka Yoke leads to the best result with a desirability of 0.98648 . This is consistent with the forecast values. 


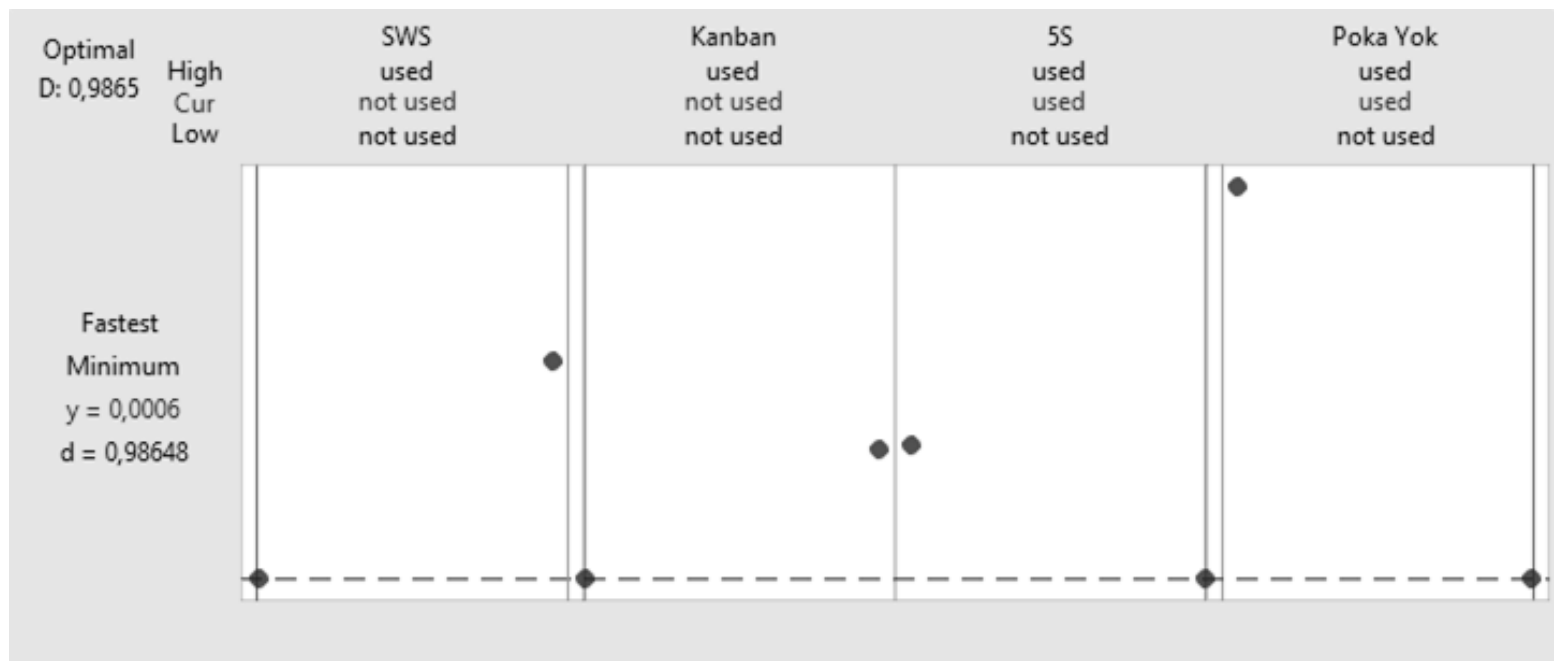

Figure 11: Target size optimization Model "Lead Time"

\subsection{Discussion and Limitations}

The findings of the business simulation show, that the use of at least one optimization method is meaningful. The contemplation of the KPI "lead time" discloses that the usage of Poka Yoke is promising and has the most significant influence on the average lead time. The strong reduction of the lead time is due to the desired goal of avoiding mistakes. Therefore, the components and assembly steps within the business simulation were designed foolproof. Due to the mentioned principles of Poka Yoke, less rework was necessary. Thus, the lead time was not affected by additional time for troubleshooting. Using Poka Yoke leads to higher success and has a low implementation effort. The colored markings of Poka Yoke simplify the production process and guarantee participants' safety, which is regarded as meaningful, too. Following the target size optimization, the combination of Poka Yoke and 5S leads to the shortest lead time. However, this does not only affect lead time, but synergy effects on other KPIs can be assumed, too. For instance, Poka Yoke will also have a strong impact on the KPI "Output". Because it reduces the lead time, more trucks can be produced at the same time, the output rises. Thus, a reduction of the lead time allows a higher productivity.

The analysis of the effectivity of optimization methods leads to the conclusion, that Poka Yoke is an influential method for process optimization. Accordingly, companies must concentrate on the gain of problem-relevant indicators based on company-specific circumstances. Only because an optimization method is efficient for one company does not mean, that this efficiency is transferable to production facilities in other companies. The effectiveness of optimization methods can vary from company to company or especially from industry to industry. Summarizing the business simulation, the supporting function of the Poka Yoke method, which leads to an increase of key performance indicators, can be confirmed.

However, it should be considered that experiments cannot be completely isolated from disturbance variables. Disturbances can be shortcomings in simulation equipment (e.g. detached sticking points for the application of the Poka Yoke method), assistance by timekeepers or distractions in upstream/ downstream process steps. In consequence, the result can never be reproduced exactly identically. A different approach of the test persons during the construction of a truck must also be taken into account. Errors occur, for example, due to different qualifications, skills and the age of the test persons. Thus, the factor "human" can be determined as a disturbance variable. The students deployed do not represent a cross-section of society or the real (production) business world. To counteract the aspect of different qualifications of the participants, only inexperienced test persons from the same study course were asked to carry out the business simulation. In doing so, learning effects can be excluded in further rounds.

\section{Summary and Future Need for Research}

The success of a company depends on economic production. Considering the current economic development, companies are forced to deal with the topic of process optimization. On the other hand, the success of an enterprise is not just down to a cost-efficient production but relies on the ability to quickly adapt to changing customer needs, too. Failing that or not responding in time, they don't stand a chance to compete in the marketplace.

To avoid this, companies can pick from a variety of theoretical approaches that are available in literature. The difficulty lies in the ability to pick the right method for the organization. Besides, enterprises can only rely on the theoretical 
definition of goals of the individual method as well as the exemplary track record of competing businesses. There are no reliable statements about the effectiveness of specific methods or different ways of how to make them available. Furthermore, the subjective assessment from lean experts can be put into consideration. There are no validated statements about the effectiveness of lean methods or their combination. To take on this problem in this research project, the following hypotheses were formulated:

"The effectiveness of Poka Yoke can be demonstrated via a developed model in form of a business simulation".

"The effectiveness of $5 S$ can be demonstrated via a developed model in form of a business simulation".

"The effectiveness of Kanban can be demonstrated via a developed model in form of a business simulation".

"The effectiveness of Standard Work Sheet can be demonstrated via a developed model in form of a business simulation".

The experiment is meant to bridge the gap between theoretical knowledge and hands-on experience. To verify the given hypotheses, the chosen methods in the business simulation were analyzed and a simulation model was developed for testing the effects of using these methods. The business simulation model with the chosen methods was tested in fortyeight rounds with new test persons in every round and with different combinations of the four methods. To compare the effectiveness of the four methods it could be demonstrated that Poka Yoke had the highest influence on the lead time in assembly. Nevertheless, the main effect diagram showed, that every lean method has a positive impact on the lead time when used. Consequently, the effectiveness of all deployed lean methods on the lead time was demonstrated through a business simulation and thereby all hypotheses can be accepted.

However, this result cannot be generalized to other types of production processes. The business simulation within the model factory reduces the complexity of realistic systems. The illustration of an assembly, as well as the execution with the model factory, was possible. It has to be considered that a full isolation of potential disturbance is not possible. Disturbance can be defects on establishments of the business simulation, e.g. detached markings of the components for the Poka Yoke methods. Therefore, further studies should be realized for a validation of the results. Moreover, other types of products can be manufactured. Maybe a product with higher complexity will have an impact on the results.

To obtain more scientifically valid results, the business simulation should be run more frequently with new and different test persons. Furthermore, other KPIs, like the output, or the adherence to delivery dates should be analyzed. The target size optimization in the software Minitab ${ }^{\circledR}$ can also be used for further analysis. An additional step involves the validation of results in the industrial application. It is recommended to conduct interviews with experts in enterprises, who already apply those methods. Another opportunity to verify would be the direct review on the shop floor.

\section{References}

Additive Soft- und Hardware für Technik und Wissenschaft GmbH, (2011), Faktorielle Versuchspläne mit Minitab, Minitab Certified Training.

Alby, T./ Braun, D./ Pfleger, S. (n.d.), Projektmanagement: Definitionen, Einführungen und Vorlagen. Projektmanagement verständlich erläutert: http://projektmanagement-definitionen.de/glossar/, 31.07.2019.

Allweyer, T. (2005), Geschäftsprozessmanagement. Strategie, Entwurf, Implementierung, Controlling, 5. Aufl., W3LVerlag, Bochum.

Amann, K./ Petzold, J. (2014): Management und Controlling - Instrumente - Organi-sation - Ziele, 2. Aufl., Wiesbaden: Springer Fachmedien.

Aparecida da Silva, L./ Pelogia Martins Damian, I./ Dallavalle de Pádua, S.I. (2012), Process management tasks and barriers. Functional to processes approach. In: Business Process Management Journal, (18)5, 762-776.

Arndt, H. (2015), Logistikmanagement, Fachmedien GmbH, Wiesbaden.

Arnheiter, E.D./ Maleyeff, J., (2005), The integration of lean management and Six Sigma. In: The TQM Magazine, 17(1), 5-18.

Asbach, M./ Kamp, F., (2014), Orientierung der Unternehmenssteuerung an Lean-Management-Grundsaetzen. In: Keuper, F./ Sauter, R. (Hrsg.), Unternehmenssteuerung in der produzierenden Industrie. Konzepte und Best Practices, p. 287-300, Springer Verlag, Wiesbaden.

Baumgaertner, G., (2006), Reifegradbasierte Gestaltung von Produktionssystemen. Theoretische und empirische Analyse eines Gestaltungsmodells, TCW Transfer-Centrum GmbH, Munich.

Becker, J.E., (2001), Implementing 5S to Promote Safety \& Housekeeping, Professional Safety, 46(8) p. 29.

Bertagnolli, F., (2018), Lean Management. Einfuehrung und Vertiefung in die japanische Management-Philosophie, Springer Gabler, Wiesbaden.

Black, J.R., (2008), Lean Production: Implementing a World-class System, Industrial Press, New York City. 
Bloetz, U., (2015), Planspiele und Serious Games in der beruflichen Bildung - Auswahl, Konzepte, Lernarrangements, Erfahrungen - Aktueller Katalog fuer Planspiele und Serious Games, Bundesinstitut fuer Berufsbildung, Bonn.

Campos, L.M.S., (2013), Lean manufacturing and Six Sigma based on Brazilian model "PNQ". In: International Journal of Lean Six Sigma, 4. Jg., Nr. 4, p. 355-369.

Clement, U./ Lacher, M., (2016), Produktionssysteme und Kompetenzerwerb - Zu den Veraenderungen moderner Arbeitsorganisation und ihren Auswirkungen auf die berufliche Bildung, Franz Steiner Verlag, Stuttgart.

Crookall, D., (2010), Serious Games, Debriefing, and Simulation/Gaming as a Discipline, In: Simulation \& Gaming, 41(6): 898-920, SAGE Publications.

Cudney, E.A./ Furterer, S.L./ Dietrich, D.M., (2013), Lean Systems: Applications and Case Studies in Manufacturing, Service, and Healthcare, CRC Press, Boca Raton.

Dall'Agnol, M./ Janes, A./ Succi, G./ Zaninotto, E., (2003), Lean Management. A Metaphor for Extreme Programming? In: Marchesi, M./ Succi, G. (Ed.), Extreme Programming and Agile Processes in Software Engineering, 4th International Conference, XP 2003, Genova, Italy, May 2003, Proceedings, Springer Verlag, Berlin Heidelberg.

Dickmann, P. (Ed.), (2015), Schlanker Materialfluss: mit Lean Production, Kanban und Innovationen, $3^{\text {rd }}$ edition, Springer Vieweg Verlag, Berlin/Heidelberg.

Dombrowski, U./ Crespo, I., (2008), A Management Approach to Lean Production System Implementation in Small and Medium-sized Enterprises - Results of a Research Project, in: R. del Olmo Martínez, R./ Galán Ordax, J.M./ Laviós Villahoz, J.J. (Eds.), Approaches and Trends on current Organization Engineering. II International Conference on Industrial Engineering and Industrial Management, September 3-5, Burgos, 995-1005.

Dombrowski, U./ Mielke, T., (2015), Ganzheitliche Produktionssysteme: Aktueller Stand und zukuenftige Entwicklungen, Springer Verlag, Berlin Heidelberg.

Duke, R., (1996), Professional Program in Simulation and Gaming Studies. College of Architecture and Urban Planning, University of Michigan, Ann Arbor.

Erlach, K., (2010), Wertstromdesign: Der Weg zur schlanken Fabrik, $2^{\text {nd }}$ edition., Springer-Verlag, Berlin/Heidelberg.

Fisher, M., (1999), Process improvement by poka-yoke. In: Work Study, 48. Jg., Nr. 7, p. 264-266.

Geiger, W./ Kotte, W., (2008), Handbuch Qualität. Grundlagen und Elemente des Qualitätsmanagements: Systeme, Perspektiven, $5^{\text {th }}$ edition, Friedich Vieweg \& Sohn Verlag, Wiesbaden.

Gericke, A./Bayer, F./Kühn, H./Rausch, T./Strobl, R. (2013): Der Lebenszyklus des Prozessmanagements. In: Bayer, Franz/Kühn, Harald (Hrsg.): Prozessmanagement für Experten, Impulse für aktuelle und wiederkehrende Themen, 11-36, Springer Verlag, Berlin/ Heidelberg.

Gibbons, P.M./ Burgess, S.C. (2010), Introducing OEE as a measure of lean Six Sigma capability. In: International Journal of Lean Six Sigma, 1(2), 134-156.

Gorecki, P./ Pautsch, P., (2013), Lean Management. Auf den Spuren des Erfolges der Managementphilosophie von Toyota und Co, $3^{\text {rd }}$ edition, Hanser Verlag, Munich.

Gorecki, P./ Pautsch, P., (2018), Praxisbuch Lean Management. Der Weg zur operativen Excellence, $3^{\text {rd }}$ edition, Hanser Verlag, Munich.

Hammer, M./ Champy, J. (1994), Business Reengineering: Die Radikalkur für das Unternehmen, 2nd edition, Campus Verlag, Frankfurt.

Herz, D./ Blätte, A., (2000), Simulation und Planspiel in den Sozialwissenschaften. Eine Bestandsaufnahme der internationalen Diskussion, LIT Verlag, Münster.

Hitzler, S./ Zürn, B./ Trautwein, F., (2011), Planspiele. Qualität und Innovation. Neue Ansätze aus Theorie und Praxis, ZMS Schriftenreihe - Band 2, Books on Demand, Norderstedt.

Ho, S.K.M., (1999), 5-S practice: the first step towards total quality management, Total Quality Management, 10(3), 347.

Jaca, C./ Viles, E./ Paipa-Galeano, L./ Santos, J./ Mateo, R., (2014), Learning 5S principles from Japanese best practitioners: case studies of five manufacturing companies. In: International Journal of Production Research, 52(15), 4574.

Kamiske, G., (2015), Handbuch QM-Methoden: Die richtige Methode auswaehlen und erfolgreich umsetzen, $3^{\text {rd }}$ edition, Hanser Verlag, Munich.

Kamiske, G./ Brauer, J.-P., (2011), Qualitaetsmanagement von A bis Z. Wichtige Begriffe des Qualitaetsmanagements und ihre Bedeutung, $7^{\text {th }}$ edition, Hanser Verlag, Munich/Wien.

Karlstedt, F. (2013), Qualitätskennzahlensystem im Projektmanagement. Entwicklung eines Kennzahlensystems zur Quantifizierung der Prozessqualität anhand der Effizienz und Effektivität der Projektabwicklung im Großanlagenbau. Zugl.: Berlin, Technische Univ., Diplomarbeit, 2011, Diplomica Verlag, Hamburg.

Kruse, W. (2009): Prozessoptimierung am Beispiel der Einführung eines neuen selbstverantwortlichen Arbeitsplanungsmodells im Hanse-Klinikum Wismar, Zugl.: Wismar, Hochsch., Bachelorthesis, 2008. Herausgegeben von: Kramer, J.W./ Neumann Szyszka, J./ Nitsch, K.W./ Prause, G./ Weigand, A./ Winkler, J., Europäischer Hochschulverlag, Bremen. 
Kuehl, S., (2009), Experiment, in: S. Kuehl, P. Strodtholz, A. Taffertshofer, Handbuch Methoden der Organisationsforschung - Quantitative und Qualitative Methoden, VS Verlag fuer Sozialwissenschaften, Wiesbaden.

Kuenzel, H. (Ed.)/ Schrader, R., (2016), Erfolgsfaktor Lean Management 2.0. Wettbewerbsfähige Verschlankung auf nachhaltige und kundenorientierte Weise, Springer Verlag, Berlin.

Kumar, S./ Harms, R. (2004), Improving business processes for increased operational efficiency. A case study. In: Journal of Manufacturing Technology Management, 15(7), 662-674.

Land, S.K./ Smith, D.B./ Walz, J.W., (2008), Practical Support for Lean Six Sigma Software Process Definition. Using IEEE Engineering Standards, John Wiley \& Sons, Inc., Hoboken.

Liker, J.K./ Meier, D. (2013): Der Toyota-Weg. Fuer jedes Unternehmen: Praxisbuch, $6 \mathrm{t}^{\mathrm{h}}$ edition, Finanzbuch-Verlag, Munich.

Lunau, S. (Ed.)/ Meran, R./ John, A./ Staudter, C./ Roenpage, O., (2014), Six Sigma + Lean Toolset. Mindset zur erfolgreichen Umsetzung von Verbesserungsprojekten, $5^{\text {th }}$ edition, Springer Gabler, Berlin/Heidelberg.

Lunau, S. (Ed.)/ Staudter, C./ von Hugo, C./ Bosselmann, P./ Mollenhauer, J.-P./ Meran, R./ Roenpage, O., (2013), Design for Six Sigma + Lean Toolset. Mindset fuer erfolgreiche Innovationen, $2^{\text {nd }}$ edition, Springer Gabler, Wiesbaden.

Morrissette, M., (2009), Time-release fix, Industrial Engineer, 41(8), 37.

Nadarajah, D./ Kadir, S. Latifah Syed Abdul, S. (2014), A review of the importance of business process management in achieving sustainable competitive advantage. In: The TQM Journal, 26(5), 522-531.

Neuhaus, R., (2016), Einleitung. In: Institut fuer angewandte Arbeitswissenschaft e.V. (Ed.): 5S als Basis des kontinuierlichen Verbesserungsprozesses, p. 1-4, Springer Verlag, Berlin Heidelberg.

Nicholas, J./ Soni, A., (2005), The Portal to Lean Production: Principles and Practices for Doing More with Less, Auerbach Publications, Boca Raton.

Ohno, T., (1988), Toyota Production System: Beyond Large-scale Production, Productivity Press, Portland/Oregon.

Ohno, T., (2013), Das Toyota-Produktionssystem, $3^{\text {rd }}$ edition, Campus Verlag, Frankfurt/New York.

Pfeiffer, W./ Weiß, E., (1992): Lean Management Grundlagen der Fuehrung und Organisation industrieller Unternehmen, Erich Schmidt Verlag, Berlin.

Pohanka, C. (2010), Six Sigma vs. Kaizen. Eine vergleichende Gegenüberstellung. Herausgegeben von: Kramer, J.W./ Nitsch, K.W./ Prause, G./ Von Schubert, A./ Weigand, A./ Winkler, J., Europäischer Hochschulverlag, Bremen.

Rath \& Strong Management Consultants (Ed.), (2008), Rath \& Strong's Six Sigma Pocket Guide. Werkzeuge zur Prozessverbesserung, TÜV Media, Köln.

Redmile, J., (2011), Clear out the clutter and get organized using visual tools, Industrial Safety \& Hygiene News 45(2), 49.

REFA, (2015), Industrial Engineering. Standardmethoden zur Produktivitaetssteigerung und Prozessoptimierung, $2^{\text {nd }}$ edition, Hanser Verlag, Munich.

Reitz, A., (2008), Lean TPM: In 12 Schritten zum schlanken Managementsystem, mi-Wirtschaftsbuch, Muenchner Verlagsgruppe, Munich.

Ristau, M. (2012), Prozessoptimierung in der Einzelteilproduktion, Diplomica Verlag, Hamburg.

Rothlauf, J. (2004), Total-quality-Management in Theorie und Praxis. Zum ganzheitlichen Unternehmensverständnis, 2. Aufl., Oldenbourg Verlag, München/ Wien.

Schmelzer, H.J./ Sesselmann, W. (2008), Geschäftsprozessmanagement in der Praxis. Kunden zufrieden stellen Produktivität steigern - Wert erhöhen, 6. Aufl., Hanser Verlag, München.

Schmitt, R.; Pfeifer, T., (2015), Qualitaetsmanagement. Strategien. Methoden. Techniken, $5^{\text {th }}$ edition, Hanser Verlag, Munich.

Schulte, C., (1991), Logistik: Wege zur Optimierung des Material- und Informationsflusses, Vahlen Verlag, Munich.

Sennheiser, A./ Schnetzler, M.(2008): Wertorientiertes Supply Chain Manage-ment. Strategien zur Mehrung und Messung des Unternehmenswertes durch SCM, Berlin [u. a.]: Springer Verlag.

Shah R, W.P., (2003), Lean manufacturing: context, practice bundles, and performance, Journal of Operations Management. Vol. 21, pp.129-149.

Shingo, S., (1986), Zero Quality Control: Source Inspection and the Poka-Yoke System, CRC Press, Boca Raton, p. 99.

Siebertz, K./ van Bebber, D./ Hochkirchen, T., (2014), Statistische Versuchsplanung - Design of Experiments (DoE), Springer Verlag, Heidelberg/Dordrecht/London/New York.

Singh, J./ Singh, H. (2012), Continuous improvement approach. State-of-art review and future implications. In: International Journal of Lean Six Sigma, 3(2), 88-111.

Sondermann, J.P., (2013), Poka Yoke - Prinzip und Techniken fuer Null-Fehler-Prozesse, Hanser Verlag, Munich.

Stagliano, A. A., (2004), Rath \& Strong's Six Sigma advanced Tools Pocket Guide. How to Use Design of Experiments, Analysis of Variance, Regression Analysis and 25 Other Powerful Tools, McGraw-Hill, New York. 
Stauberg, J. R./ Deuse, J./ Baudzus, B. (2009), Didaktische Hilfsmittel zur Umsetzung schlanker Produktionssysteme, In: ZWF Zeitschrift für wirtschaftlichen Fabrikbetrieb, 104 (10), pp. 847-852.

Stiller, G. (n.d.), Optimierung: http://www.wirtschaftslexikon24.com/d/optimierung/optimierung.htm, 06.07.2017.

Sugimori, Y./ Kusunoki, K./ Cho, F./ Uchikawa, S., (1977), Toyota production system and Kanban system: materialization of just-in-time and respect for human systems. International Journal of Production Research 15 (6), pp. 553-564.

Suri, R., (2010), It's About Time: The Competitive Advantage of Quick Response Manufacturing, Taylor and Francis Group, LLC, New York, p. 130.

Suzaki, K., (1993), The new shopfloor management, Empowering people for continuous improvement, Free Press, New York.

Takeda, H., (2014), Das synchrone Produktionssystem: Just-in-Time fuer das ganze Unternehmen, $7^{\text {th }}$ edition, Vahlen Verlag, Munich.

Thaler, K. (1999), Supply Chain Management. Prozessoptimierung in der logistischen Kette, Fortis Verlag, Köln.

Theden, P./ Colsman, H., (2013), Qualitaetstechniken. Werkzeuge zur Problemloesung und staendigen Verbesserung, $5^{\text {th }}$ edition, Hanser Verlag, Munich.

Ulrich, M., (2006), Komplexität anpacken. Mit Planspielen erfolgreiches Handeln erleben, In: Tagungsband zur 7. Werner-Kollath-Tagung, Komplexität erkennen, Zukunft gestalten, Ernährungsökologie als integrativer Ansatz für Wissenschaft und Praxis, pp. 1-24.

Verein Deutscher Ingenieure: VDI-Richtline 2870 (2012) Blatt 1. Ganzheitliche Produktions-systeme. Methodenkatalog, Köln: Beuth Verlag.

Weber, R., (2009), Zeitgemaeße Materialwirtschaft mit Lagerhaltung: Flexibilitaet, Lieferbereitschaft, Bestandsreduzierung, Kostensenkung - das deutsche Kanban, $9^{\text {th }}$ edition, expert Verlag, Renningen.

Wieczorek, D., (2009), Statistische Versuchsplanung. Angewandt auf technische Systeme. In: Bandow, G./ Holzmüller, H. H. (Ed.), „Das ist gar kein Modell!“ Unterschiedliche Modelle und Modellierungen in Betriebswirtschaftslehre und Ingenieurwissenschaften, Gabler Verlag, Wiesbaden, pp. 169-187.

Womack, J.P./ Jones, D.T., (1996), Lean Thinking: Banish Waste and Create Wealth in Your Corporation, Simon \& Schuster, New York.

Womack, J.P./ Jones, D.T., (2013), Lean thinking. Ballast abwerfen, Unternehmensgewinne steigern, $3^{\text {rd }}$ edition, Campus Verlag, Frankfurt am Main.

Yagyu, S., (2009), Das synchrone Managementsystem, FinanzBuch Verlag GmbH, München.

Zelewski, S./ Hohmann, S./ Hügens, T., (2008), Produktionsplanungs- und -steuerungssysteme. Konzepte und exemplarische Implementierungen mithilfe von $\mathrm{SAP}{ }^{\circledR} \mathrm{R} / 3{ }^{\circledR}$, Oldenbourg Verlag, Munich.

Zidel, T.G., (2006), A Lean Guide to Transforming Healthcare: How to implement Lean Principles in Hospitals, Medical Offices, Clinics and Other Healthcare Organisations, ASQ Quality Press, Milwaukee/Wisconsin.

\section{Biographies}

Dr.-Ing. Patrick Pötters, M.Sc. M.Eng. is Visiting Professor at the University of Applied Sciences Koblenz, Faculty of Operations Management/ Germany. He holds a PhD from the RWTH Aachen University. He is a certified Senior Lean Expert as well as Six Sigma Black Belt. Furthermore, he is working in different consultancy projects, especially lean six sigma implementations. His research focus is on process optimization methods on the shop floor, lean six sigma and quality management.

Prof. Dr.-Ing. Robert H. Schmitt has been a Professor at the Laboratory for Machine Tools and Production Engineering (WZL) at RWTH Aachen University since July 2004. He is a member of the Boards of Directors of Fraunhofer IPT and WZL. Following his studies in electrical engineering, Professor Schmitt worked as a chief engineer at WZL. In 1997, he joined the quality-management executive staff at a leading producer of commercial vehicles and would be in charge of production at various production locations; finally, he was entrusted with overseeing the assembly of commercial vehicles of up to 18 tons. On September 1, 2004, he was appointed Director of the Department of Production Metrology and Quality Management. Since January 2005, he has been a member of the Board of Directors of Fraunhofer Institute for Production Technology IPT.

Prof. Dr. Bert Leyendecker is Professor of Operations Management and Project Management at the University of Applied Sciences Koblenz/ Germany. He is Lean Six Sigma Master Black Belt and senior project management expert. He used to work for Johnson \& Johnson before in different roles as value chain manager, business excellence champion as well as process and project engineer. He holds a PhD from the University of Newcastle upon Tyne and a first degree from TH Koeln. Bert Leyendecker is an active member of various organisations such as Gesellschaft für 
International Journal of Industrial Engineering and Operations Management (IJIEOM)

Volume. 2, No. 1, October 2020

Qualitätswissenschaften, DIN/ ISO, Deutsche Gesellschaft für Qualität. Furthermore, he is board member at the European Six Sigma Club.

Jasmin Ohlig, M.Sc. is a research associate at the University of Applied Sciences Koblenz, Faculty of Operations Management/ Germany. She is a certified Six Sigma Black Belt. She mainly works in the research project "SAPEQ Smart Data Analytics in der Produktentstehung zur Sicherstellung der Qualität bei KMU“ (IGF 20889N). 